\title{
Recent apprise on coronavirus and its terrible insinuations
}

\author{
Sankha Bhattacharya ${ }^{1}$ (i) Priyanka Sharma $^{2} \cdot$ Harshita Mathur $^{2} \cdot$ Haamid Rasheed $^{2}$. \\ Saranjit Singh $^{2} \cdot$ Geeta Rajput $^{2} \cdot$ Suyash $_{\text {Agnihotri }}{ }^{2} \cdot$ Puneet Nirmal $^{2}$. \\ Sukhbir Kaur ${ }^{2}$
}

Received: 7 March 2020/Accepted: 6 April 2020/Published online: 18 April 2020

(C) Indian Virological Society 2020

\begin{abstract}
Epidemically increased evidence reveals that the link between the 2019-nCoV and other similar strain of coronaviruses circulating in bats and specifically the Rhinopodous bat sub-species. These sub-species are ample and widely present in Southern China, Middle East Africa and Europe. Recent studies show that more than $500 \mathrm{CoV}$ have been identified in bats in China. The Center for Diseases Control and Prevention and the World Health Organization maintains a website that is updated frequently with new cases of MERS-CoV infection. As per WHO Situation report 16th, 24,554 number of cases confirmed globally out of which $99.22 \%$ cases from china. A new coronavirus (2019-nCoV) is causing respiratory syndrome mostly in Hubei Province, China. Corona Virus spread over 24 countries including Japan, India, Korea, and other countries 2019-CoV infection vary from mild, moderate or severe illness; the later includes severe pneumonia, ARDS, sepsis and septic shock. There are two diagnostic tests for coronavirus infection i.e. molecular test and serology test. In this review article there are the various recent cases of the patients that are suffering from the corona virus, the outcome of these studies is that corona virus infection is an epidemic disease which affects Central Nervous System (CNS).
\end{abstract}

Keywords Coronavirus - Middle east respiratory syndrome coronavirus (MERS-CoV) · New coronavirus

Sankha Bhattacharya sankhabhatt@gmail.com

1 Department of Pharmaceutics, ISF College of Pharmacy, GT Road (NH-95), Ghal Kalan, Moga, Punjab 142001, India

2 Department of Quality Assurance, ISF College of Pharmacy, Moga, Punjab 142001, India
(2019-nCoV) · Human coronavirus NL63 - rRT-PCR tests · Hem agglutinin esterase (HE)

\section{Introduction}

Coronaviruses are a group of viruses that cause diseases in humans, mammals, and birds. In humans, the virus causes respiratory tract infections which are mild but may be lethal in some cases. Coronaviruses are a group of an RNAvirus and also known as a 2019-nCov virus. Coronaviruses are viruses in the subfamily Orthocoronaviridae, of family Coronaviridae in the order Nidovirales. Coronaviruses are enveloped viruses and have a positive-sense single-stranded RNA genome with a nucleocapsid of helical symmetry $[8,31]$. The genomic size of coronavirus varies from 26 to 32 kilobase [7]. Coronaviruses are categorized into four genera i.e. alpha, beta, delta and gamma, where alpha and beta are responsible for causing infection in humans [17]. There are seven strains of human coronaviruses Viz. Human coronavirus 229E(HCoV-229E), Human coronavirus OC43(HCoV-OC43), SARS-CoV, Human coronavirus NL63(HCoV-NL63, New Heaven Coronavirus), Human Coronavirus HKU, Middle East Respiratory Syndrome Coronavirus (MERS-CoV) previously known as novel coronavirus 2012 and HCoV-EMC, Novel coronavirus (2019-nCoV) also known as Wuhan pneumonia or Wuhan coronavirus. The coronaviruses HCoV-229E, -NL63, -OC43 and -HKU1 frequently circulate in human population and cause respiratory infection in adults and children. The incubation period for human coronavirus is $2-5$ days [15]. As it is communicable disease and transfer from one person to another person through a droplet and direct contact [9]. The recent identification of fourth human coronavirus, HCoV-NL63 was 
diagnosed from a 7-month-old child who suffers from bronchiolitis and conjunctivitis. Symptoms of coronavirus are feeling tired, difficulty in breathing, fever, coughing and sore throat. As the symptoms are similar to other respiratory diseases including flu and common cold. In this review, we have explained the actual mechanism of coronavirus and its overexpression in the cell membrane (Fig. 1).

\section{Laboratory test for MERS-CoV}

\section{Molecular test}

For identification of active infection Serology test was performed. For the surveillance purpose, serology test was performed. However, it has its own limitation i.e., it cannot be considered as diagnostic test. In this test antibodies to MERS-CoV can be finalized from previous infections [34]. The populations of certain places, which are disease-ridden with MERS infection are suspectable for Molecular test and clinical tests to identify active infections of MERSCoV [22]. To identify the viral RNA within reckonable samples, a molecular test called Real-time reverse

\section{Mechanism of Action of Corona Virus:}

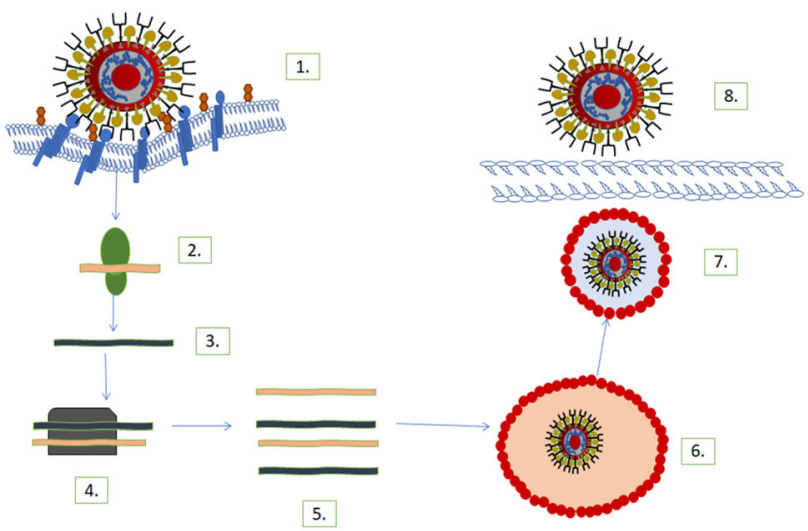

Fig. 1 Introduction (1) of Virus into the host cell cytoplasm. The replication of corona virus occurs in host cell. Firstly, the virus binds to the host cell via spike (S) protein[Corona virus has five structural proteins in its genomes and those are- Spike (S), Membrane (M), Envelope (E) glycoprotein, Hem agglutinin Esterase(HE) and Nucleocapsid $(\mathrm{N})$ protein] and the entry of virus begins. (2) After the entry into cytoplasm of host cell, the virus releases its RNA genome. The RNA genome of corona virus is a positive single-stranded RNA. (3) Genomic RNA. (4) Then this single stranded RNA by translation process produces precursor proteins on vesicles. (5) The copies of $\mathrm{N}$ protein are formed. (6) Then this protein gets entered into the Endoplasmic reticulum membrane. (7) And they get stored in Golgi bodies. (8) After, they are transported out of the cell membrane and then they infect other cells in the host body transcription-polymerase chain reaction (rRT-PCR) are vividly used. For identification and confirmation of MERS$\mathrm{CoV}$ infection entails, as per Central for disease control and prevention (CDC) there must be either a positive rRTPCR result for at least two definite genomic targets or single positive target with the sequencing of a second target. As per CDC the United States has approved an rRTPCR assay for MERS-CoV. The test is thru under the buff of an Emergency Use Authorization. But human error, poor laboratory conditions and ignorance while testing the samples is such prevalent factors which could affect the capability and proficiency of rRT-PCR test. For this rRTPCR assay, CDC recommended collecting multiple samples, including lower and upper respiratory sample, serum and stool specimen. CDC considers a patient under examination to be negative for active MERS-CoV infection when one negative rRT-PCR test on the mentioned specimen. CDC consider MERS patient to be negative for active MERS-CoV infection followed by two successive negative rRT-PCR tests on all samples [1].

\section{Serology tests}

The peoples who had infection to MERS-CoV, serology test helps to identify antibody from them. These types of antibody have the capability to attack, attenuate, kill the hosted virus within the immune system. The presence of antibodies to MERS-CoV shows that a person had been formerly diseased with the virus and develops an immune response. Confirmation to date recommends there may be a wider range of MERS disease than was initially thought. For example, a public health investigator has recognized individuals who are PCR-positive but have no MERS symptoms; we do not know if MERS-CoV can be spread by these people. CDC has a two-phase methodology for serology testing, using two screening tests and one confirmatory test to distinguish antibodies to MERS-CoV [6]. The enzyme-linked immunosorbent assay (ELISA) is a screening tests to detect the occurrence and concentration of specific antibodies that is bind to a viral protein. CDC recommended ELISA test for antibodies against two different MERS-CoV proteins viz. nucleocapsid (N) and spike (S). To identify the neutralizing antibodies, the microneutralization assay is a good confirmatory test which helps to measure specific antibodies in serum specimens. However, compared to ELISA, the microneutralization assay is a laboratory intensive and time-consuming method and requires at least 5 days before the result are available. If a clinical sample is found to be positive either by ELISA or microneutralization, the specimen is determined to be confirmed positive [5]. If a clinical sample is found to be positive by both ELISAs, and negative by microneutralization, the sample is determined to be intermediate. If a 
clinical sample is found to be positive by only one ELISA and negative by microneutralization, the sample is determined to be negative [18]. In the end, a final determination of a confirmed positive serology the result needs to be a positive ELISA test and confirmation by microneutralization assay. MERS-CoV serology test is used for surveillance test, not for diagnostic purpose-these are the tools which developed in response to the MERS-CoV outbreak.

\section{Comparison of Wuhan coronavirus with MERS and SARS}

The comparison of Wuhan coronavirus with MERS and SARS is described in Table 1.

\section{History}

In 1965, two scientists Tyrell and Bynoe studied the human coronavirus named B814 found in human embryonic tracheal organ cultures obtained from the respiratory tract of a person with common cold. The existence of an infectious agent was demonstrated by inoculating the medium form these cultures in human volunteers. In this experiment, colds were produced but the growth of agents does not occur. At the same time other two scientists, Hamre and Procknow got to succeed in growing virus with unusual properties in tissue culture from samples which were picked up from adults with colds. Hamre named this virus as 229E (Hamre's virus) [12]. In the late 1960s, Tyrell with a group of scientists worked on human strains and other animal viruses which included infectious bronchitis virus, mouse hepatitis virus and transmissible gastroenteritis virus of swine which were morphologically the same as seen through electron microscopy [12]. This new category of viruses was called coronavirus and was accepted as new genus of viruses. Further research gives more information about the epidemiology of human respiratory coronaviruses like it was found that in temperate climates, respiratory coronavirus infections occur more often in the winter and spring [29]. After three decades of discovery, human strains OC43 and 229E were studied. Like many other viruses the reinfection was common. As the research continues to explore the pathogenicity and epidemiology of the human coronavirus, the importance and number of animal coronaviruses were growing rapidly. In 2003, the new virus SARS-CoV (Severe Acute Respiratory Syndrome coronavirus) was identified which first infected humans in Southern China. SARS-CoV killed 774 people and at least 8000 people were infected [23]. SARS infection affected 29 countries. Since 2004, there have not been any known cases in the world [16]. The transmission of SARS is primarily from person to person. Symptoms are like influenzalike and include fever, malaise, headache, diarrhea, and shivering. The evolution of this virus demonstrated that this virus is not stable virus and can adapt to become more virulent, even lethal, to humans. After that another outbreak in Saudi Arabia in 2012 cause many deaths and later spread to other countries. It was called Middle East Respiratory Syndrome coronavirus (MERS CoV) as its origin was Middle East. The spread of infection occurred worldwide; however, most cases of deaths occurred in the Middle East. From2012 to 2018, the total number of cases reported was 2274 from 27 countries, out of which 817 associated deaths were reported. There are no further reports of cases of MERS-CoV.But now in December

Table 1 The comparison of Wuhan coronavirus with MERS and SARS

\begin{tabular}{|c|c|c|c|c|}
\hline Contents & Wuhan coronavirus (2019-nCoV) & $\begin{array}{l}\text { The Middle East } \\
\text { Respiratory } \\
\text { Syndrome(MERS) }\end{array}$ & $\begin{array}{l}\text { Severe Acute Respiratory } \\
\text { Syndrome (SARS) }\end{array}$ & $\begin{array}{l}\text { The common cold caused by } \\
\text { coronavirus }\end{array}$ \\
\hline Origin & $\begin{array}{l}\text { In December 2019, it was first } \\
\text { identified in Wuhan (China) }\end{array}$ & $\begin{array}{l}\text { In } 2012 \text { in Saudi Arabia } \\
\text { first case was reported }\end{array}$ & $\begin{array}{l}\text { First case was identified in } \\
2002 \text { in southern china }\end{array}$ & $\begin{array}{l}\text { Four strains of coronavirus } \\
\text { strains found to be } \\
\text { responsible for } 15-30 \% \text { of } \\
\text { common cold }\end{array}$ \\
\hline Transmission & $\begin{array}{l}\text { Spread by coming in contact with } \\
\text { infected animal. And between } \\
\text { humans occurs through close } \\
\text { contact }\end{array}$ & $\begin{array}{l}\text { By touching infected } \\
\text { camels or drinking their } \\
\text { milk or eating their } \\
\text { meat }\end{array}$ & $\begin{array}{l}\text { Spread from bats. } \\
\text { Transmitted mainly } \\
\text { between humans through } \\
\text { close contact }\end{array}$ & $\begin{array}{l}\text { Infection occurs by close } \\
\text { contact with infected humans } \\
\text { that carries virus }\end{array}$ \\
\hline Cases & $\begin{array}{l}\text { At least } 40,553 \text { cases and } 903 \text { deaths } \\
\text { as on } 10 \text { February } 2020\end{array}$ & $\begin{array}{l}2,494 \text { cases, } 858 \text { deaths } \\
\text { (as on Nov. 2019). The } \\
\text { mortality rate was } 34 \%\end{array}$ & $\begin{array}{l}8,098 \text { cases, } 774 \text { deaths. } \\
\text { The mortality rate was } \\
10 \%\end{array}$ & $\begin{array}{l}\text { Generally nonlethal with rare } \\
\text { exceptions } \\
\text { Millions of cases each year }\end{array}$ \\
\hline $\begin{array}{c}\text { Current } \\
\text { status }\end{array}$ & $\begin{array}{l}\text { Cases were mostly reported in China } \\
\text { and spread to at least } 21 \text { other } \\
\text { countries }\end{array}$ & $\begin{array}{l}\text { Arabian peninsula was } \\
\text { affected with } 80 \% \text { in } \\
\text { Saudi Arabia }\end{array}$ & $\begin{array}{l}87 \% \text { of cases were in China } \\
\text { and Hong Kong }\end{array}$ & $\begin{array}{l}\text { Occurs year around but more } \\
\text { common in fall/winter }\end{array}$ \\
\hline
\end{tabular}


2019, there was an epidemic of new novel coronavirus in the city of Wuhan, China and was named as 2019-nCoV [14]. This infection is closely related to SARS-CoV and MERS-CoV [30]. In December 2019, WMHC reported 27 cases of viral Pneumonia. Most of the people who were infected had exposure to the Huanan Seafood Market where poultry bats, snakes and other wildlife animals were sold. The cause of viral pneumonia was not SARS, MERS, influenza virus or adenovirus. On January 10 reports came that the newly identified 2019-nCoV has been isolated from patients with the help of reverse-transcription polymerase chain reaction methods. On Jan 2020, 217 patients were infected with $2019-\mathrm{nCoV}$ out of which 9 patients died. There are more than 20,623 confirmed cases and at least 427 people have died as of $3 \mathrm{Feb} 2020$. The virus has spread to at least to 20 countries including US, Australia, Thailand, Hong Kong, Taiwan, Macau, Singapore, Japan, South Korea, France, Malaysia, Canada, Germany, Nepal, India and UAE.

\section{Mode of COVID-19 transmission and its prevention}

After close introspection from the chinses government it was tangible that, the outbreak of COVID-19 was ignited from fish and wild animal market of Wuhan city, china during November 2019 [33]. The virus has prominent intention to grown itself within the serum or raw blood within the mutilated bodies of animals, birds and fishes. After proper incubation within the animal blood, the virus transmission occurs due to the human trespassing and mobilization. As per WHO guideline, to prevent an individual from contamination, one can frequently wash his/her hand using sanitizer (containing 70\% ethanol, 15\% hydrogen peroxide, $15 \%$ deionised water), avoid unprotected animal contacts, use of FFP1-3 mask. As per WHO's most recent guideline (March 31, 2020) a patient with acute respiratory illness; with certain symptoms of cough, shortness of breath and a history of traveling in foreign territory, is susceptible for community transmission of COVID-19 disease. He/she must be treated in quarantine at list for 14 days.

\section{Anti COVID-19 activity of chloroquine derivative and recent Hydroxychloroquine clinical research}

Chloroquine has some devastative and quandary effects against any kind of RNA virus i.e., hepatitis $\mathrm{A}$ and $\mathrm{C}$, rabies, polio, HIV, influenza A and $\mathrm{B}$, influenza A H5N1, Lassa, Zika, Hendra, Nipah and Ebola virus [27]. Chloroquine has also some lethal effects against some DNA virus as well, such as hepatitis B virus and herpes simplex virus. But unfortunately, very few clinical researches have been carryforward to detect the antiviral activity of Chloroquine.
As far as the Corona virus pandemic is concerned, benefits of chloroquine were remarkably reported for SARS-CoV-1. In in-vitro cell line studies, it was confirmed that Chloroquine has significant inhibitory effects on the replication of HCoV- 229E in epithelial lung cell cultures. The Chloroquine has been most prominently active against Middle East respiratory syndrome coronavirus (MERS-CoV). The Chloroquine has significant impact on establishing endolysosomal pathway, as SARS-CoV-1 virus try to vandalize this pathway, hence Chloroquine could be very effective against novel corona virus. A recent paper stated that both chloroquine and antiviral Remdesivir inhibited SARS-CoV-2 in vitro, and proposed that these drugs to be assessed in human patients suffering from COVID-19. As far as its mechanism of action is concern against novel corona virus, it has multiple mechanisms in which in stepby-step it inhibits the pre entry of virus penetration within the cellular surface receptors. The Chloroquine was found to have inhibitory effects against enzyme called quinone reductase 2; a structural neighbor of UDP- $\mathrm{N}$-acetylglucosamine 2-epimerases, which is involved in the biosynthesis of sialic acids. The Chloroquinoline, interferes the biosynthesis of sialic acid, by which human coronavirus $\mathrm{HCoV}-\mathrm{O} 43$ and the orthomyxoviruses cannot utilize sialic acid moieties as receptor, due to which the virial glycosylation on virus cell surface receptor would stop. Due to alkylation of endosome, Chloroquine shows in-vitro antiviral effect when added to Vero cells prior to virus exposure. The mechanism is likely to be rapid annulment of virus endosome fusion with fluctuation of endosomal $\mathrm{pH}$ through endocytosis.

Based on the initial studies and positive outcomes of Chloroquine, Indian Council of Medical Research (ICMR) on March 24, 2020 suggested that, those patients who are corona positive and the doctors and other healthcare professionals who are handling COVID-19 patients are advised to take Hydroxychloroquine; a Chloroquinoline derivative, as a preventive drug. As, Hydroxychloroquine; an antimalarial drug has assumed prophylactic effects against COVID-19. But as per Forbes article (By Willam A. Haseltine, March 25, 2020) Hydroxychloroquine has ineffective treatment of patients hospitalized with COVID19. The small controlled trails were conducted in Shanghai Public Health Clinical Center, China with 15 patients by giving $400 \mathrm{mg}$ hydroxychloroquine dose for 7 days. The results are not that much surprising, when the treatment group was compared with the controlled group after CT scans, it was observed that treatment group has less significance difference than the controlled group. Total $93 \%$ of patients in the control group tested negative for COVID19 after 7 days compare to $86.7 \%$ of patients in the Hydroxychloroquine treated group. The results were not that much favorable and statistically indistinguishable. 


\section{Consolidated situation reports of WHO on March 31, 2020}

As per WHO, on March 31, 2020 no new country reported new cases on COVID-19 for the last $24 \mathrm{~h}$. However, the numbers of infected cases are alarming. Globally almost 75,890 confirmed cases and 36,405 deaths were reported till March 31, 2020. As per WHO report, more than 800,000 surgical masks, 873,000 gloves, 54,000 N95 masks and 24,000 face shields were exported in 75 countries along with COVID-19 testing kits to 126 countries by Operations Support and Logistics (OSL).

\section{Case studies}

\section{Japan}

On 15 January 2020, the case of coronavirus (2019-nCoV) was reported by Ministry of Health, Labor and Welfare, Japan (MHLW) from Wuhan, Hubei Province, China [19].

The patient was male, age 30-39 years, living in Japan. The patient traveled to Wuhan, China in late December and had a fever on 3 January 2020 while staying in Wuhan. He did not visit the Huanan Seafood Wholesale Market or any other live animal markets in Wuhan [13]. He has indicated that he was in close contact with a person with pneumonia. On 6 January, he returned to Japan and tested negative for influenza when he visited a local clinic on the same day [21]. On 10 January 2020, due to his continued symptoms of cough, sore throat, and fever, he visited a local hospital and was found to have abnormal chest $\mathrm{x}$-ray with infiltrates [32]. He was admitted to the hospital on the same day and had remained fevered [10]. On 14 January, his attending doctor notified the case to a local public health authority under the surveillance system for "Unidentified Serious Infectious Illness". Samples were collected and sent to the National Institute of Infectious Diseases (NIID), and at NIID, polymerase chain reaction (PCR) testing and sequencing were performed twice, which identified very small amount of 2019-nCoV RNA on 15 January 2020 [13].

\section{Korea}

On 20 January 2020, the first case of novel coronavirus was reported by National IHR Focal Point (NFP) for the Republic of Korea in the Republic of Korea. The patient was a 35-year-old female, Chinese national, residing in Wuhan, Hubei province in China.

The case-patient had developed fever, chill, and muscle pain on 18 January while in Wuhan. She visited a local hospital in Wuhan and was initially diagnosed with a cold.
On 19 January, the case-patient was detected with fever $\left(38.3{ }^{\circ} \mathrm{C}\right)$ upon arrival at the Incheon International Airport. The case-patient was transferred to a nationally designated isolation hospital for testing and treatment. The patient was tested positive was confirmed positive for novel coronavirus (2019-nCoV) on 20 January by sequencing at the Korea Centers for Disease Control and Prevention (KCDC). The patient had chills, runny nose, and muscle pain. The case-patient did not report visiting any markets, including Huanan Seafood Wholesale Market, nor did she have known contact with confirmed 2019-nCoV cases or wild animals in Wuhan city. The case-patient is currently under isolation, receiving treatment and is in a stable condition [4].

\section{Thailand}

On 13 January 2020, the first imported case of coronavirus was reported by the Ministry of Public Health (MPH), Thailand from Wuhan, Hubei Province, China.The patient was a 61-year-old Chinese woman living in Wuhan City, Hubei Province, China. On 5 January 2020, she developed fever with chills, sore throat and headache. On 8 January 2020, she took a direct flight to Thailand from Wuhan City together with five family members in a tour group of 16 people. The traveler with febrile illness was detected on the same day by thermal surveillance at Suvarnabhumi Airport (BKK), Thailand, and was hospitalized the same day [26]. After the temperature check and initial assessment, she was transferred to the hospital for further investigations and treatment [2]. She reported a history of visiting a local fresh market in Wuhan on regular basis; however, she did not report visiting the Huanan South China Seafood Market from where most of the cases were detected [3]. Samples tested positive for coronaviruses by reverse transcriptasepolymerase chain reaction (RT-PCR) on 12 January 2020 [25]. The genomic sequencing analysis performed by Emerging Infectious Diseases Health Science Center, the Thai Red Cross Society (EID-TRC) and the Thai National Institute of Health (Thai NIH), Department of Medical Sciences confirmed that the patient was infected with the novel coronavirus (2019-nCoV) which was isolated in Wuhan, China (for more information, please see the Disease Outbreak News published on 12 January 2020).

\section{India}

In India the patient was detected with Novel coronavirus in Kerala's Thrissur district and the patient kept in an isolation ward while the number of people under observation [28]. The condition of the woman patient, a medical student from Wuhan University, was "stable" [11]. The woman, now in an isolation ward at the general hospital in 
Thrissur, is likely to be shifted to the Medical College Hospital there soon. Health officials were awaiting a result of one more test-Gene sequencing only after which it can be stated that the patient was affected with the virus [24]. Three others, who had returned from China, are also in isolation wards in Thrissur. Of the four students who returned from China, one of them has tested positive. Of the total 1053 people under observation after traveling to China, as many as 247 arrived in the state on Thursday. While 15 people, including seven who got admitted on Thursday, are under observation in isolation wards at various hospitals across the state, the remaining are under home quarantine. So far, a total of 24 samples have been sent to the National Institute of Virology in Pune for testing and 15 of them turned out to be negative while that of the woman tested positive [20].

\section{Cases and deaths country wise}

The details of coronavirus registered cases and registered deaths in different countries are given in Table 2.

\section{Approved corona virus medicament}

After long hurdle and extensive research, scientists have come to a conclusion that Flavilavir; an anti-viral drug has the potential to eradicate novel coronavirus. This drug now subsequently promoted for marketing by National Medical Products Administration since the outburst. The Flavilavir, was developed by Zhejiang Hisun Pharmaceutical Company. From the clinical research data, it is postulated that Flavilavir could play a game changer in the management of novel coronavirus.

\section{Conclusion}

In the above study of corona virus, there are the various recent cases of corona virus affected patient (human beings) are addressed in the latest by 2020 . So, in the above article various causative agents and the mechanism of action of the corona virus are determined and studied. The corona virus is of the various kinds and the most lethal corona virus is Wuhan Corona virus (2019). There are the two different diagnostic tests of the corona virus are discussed in the above study. Now days corona virus is spreading in the various regions of the world, so maintain good hygienic conditions, so that one should live a healthy life.
Table 2 Coronavirus registered cases and registered deaths in different countries (As per WHO Report, March 31, 2020)

\begin{tabular}{lrrr}
\hline Country & Total cases & Total confirmed new cases & Total death \\
\hline China & 82,545 & 98 & 3314 \\
Japan & 1953 & 87 & 56 \\
Singapore & 879 & 35 & 3 \\
New Zealand & 600 & 48 & 1 \\
Thailand & 1524 & 0 & 9 \\
Republic of Korea & 9786 & 125 & 162 \\
Italy & 101,739 & 4050 & 11,591 \\
Spain & 85,195 & 6398 & 7340 \\
Australia & 4359 & 393 & 18 \\
The United Kingdom & 22,145 & 2619 & 1408 \\
Germany & 61,913 & 4615 & 583 \\
United States of America & 140,640 & 17,987 & 2398 \\
France & 43,977 & 4335 & 3017 \\
Netherlands & 11,750 & 884 & 864 \\
UAE & 611 & 41 & 5 \\
Canada & 6317 & 662 & 66 \\
Brazil & 4256 & 352 & 136 \\
Philippines & 1546 & 128 & 78 \\
India & 1071 & 0 & 29 \\
Nepal & 5 & 0 & 0 \\
Israel & 4831 & 240 & 17 \\
Pakistan & 1865 & & 25 \\
\hline & & 0 & 0
\end{tabular}




\section{Compliance with ethical standards}

Conflict of interest The authors declare no conflict of interest.

Research involving human and animal rights In this review article, no research involving in human participants.

Informed consent No informed consent was needed for this review articles.

\section{References}

1. Al-Omari A, et al. MERS coronavirus outbreak: Implications for emerging viral infections. Diagn Microbiol Infect Dis. 2019;93(3):265-85.

2. Bernard SA, et al. Treatment of comatose survivors of out-ofhospital cardiac arrest with induced hypothermia. N Eng J Med. 2002;346(8):557-63.

3. Bernstein TP, Lü X. Taxation without representation in contemporary rural China. Cambridge: Cambridge University Press; 2003.

4. Ciccocioppo R, et al. Autologous bone marrow-derived mesenchymal stromal cells in the treatment of fistulising Crohn's disease. Gut. 2011;60(6):788-98.

5. Coleman RM, et al. Determination of herpes simplex virus typespecific antibodies by enzyme-linked immunosorbent assay. J Clin Microbiol. 1983;18(2):287-91.

6. El-Kahlout RA. Seroprevalence of Anti-Mers-CoV IgG in two groups of Qatar population: blood donors and case contacts. MS thesis. 2017.

7. El Wahid AA, Patel P, Heidenreich D, Hubert FT, Weidmann M. Reverse transcription recombinase polymerase amplification assay for the detection of Middle East respiratory syndrome coronavirus. PLoS Curr. 2013. https://doi.org/10.1371/currents. outbreaks.62df1c7c75ffc96cd59034531e2e8364.

8. Gelderblom HR. Structure and classification of viruses, in Medical Microbiology. 4th ed. Galveston: University of Texas Medical Branch; 1996.

9. Hawker J, et al. Communicable disease control handbook. Hoboken: Wiley; 2008.

10. Jefferson G. On the saccular aneurysms of the internal carotid artery in the cavernous sinus. Br J Surg. 1938;26(102):267-302.

11. Jiang L, et al. Retrospective survey of 452 patients with inflammatory bowel disease in Wuhan city, central China. Inflamm Bowel Dis. 2006;12(3):212-7.

12. Kahn JS, McIntosh K. History and recent advances in coronavirus discovery. Pediatric Infect Dis J. 2005;24(11):S223-S22727.

13. Khan N, Naushad M. Effects of corona virus on the world community. 2020. Available at SSRN 3532001.

14. Kim K, et al. Middle East respiratory syndrome coronavirus (MERS-CoV) outbreak in South Korea, 2015: epidemiology, characteristics and public health implications. J Hosp Infect. 2017;95(2):207-13.

15. Lessler $\mathbf{J}$, et al. Incubation periods of acute respiratory viral infections: a systematic review. Lancet Infect Dis. 2009;9(5):291-300.

16. Leung GM, et al. The epidemiology of severe acute respiratory syndrome in the 2003 Hong Kong epidemic: an analysis of all 1755 patients. Ann Int Med. 2004;141(9):662-73.

17. Li G, et al. Coronavirus infections and immune responses. J Med Virol. 2020;92:424-32.
18. Linde G, Granström M, Orvell C. Immunoglobulin class and immunoglobulin $\mathrm{G}$ subclass enzyme-linked immunosorbent assays compared with microneutralization assay for serodiagnosis of mumps infection and determination of immunity. J Clin Microbiol. 1987;25(9):1653-8.

19. Corman VM, Landt O, Kaiser M, Molenkamp R, Meijer A, Chu DKW, Bleecker T, et al. Detection of 2019 novelcoronavirus (2019-nCoV) by real-time RT-PCR. Eurosurveillance. 2020;25(3):2000045.

20. Organization WH. SARS: how a global epidemic was stopped. Manila: WHO Regional Office for the Western Pacific; 2006.

21. Pan M, et al. Human infection with a novel, highly pathogenic avian influenza A (H5N6) virus: virological and clinical findings. J Infect. 2016;72(1):52-9.

22. Pascal KE, et al. Pre-and postexposure efficacy of fully human antibodies against Spike protein in a novel humanized mouse model of MERS-CoV infection. Proc Natl Acad Sci. 2015;112(28):8738-43.

23. Peiris JS, et al. The severe acute respiratory syndrome. $\mathrm{N}$ Eng $\mathrm{J}$ Med. 2003;349(25):2431-41.

24. Purushothaman J, Innah SJ. Clinical outcome of platelets transfusions using platelet-rich plasma platelets and buffy coat removed platelets in patients with thrombocytopenia. Asian J Trans Sci. 2019;13:1.

25. Reddy G, et al. Prevalence of groupa rotavirus in diarrhoeic goat kids from organized goat farm. Indian $\mathbf{J}$ Comp Microbiol Immunol Infect Dis 2014;35(1):9-12.Immunol Infect Dis

26. Runge-Ranzinger $S$, et al. Dengue disease surveillance: an updated systematic literature review. Trop Med Int Health. 2014;19(9):1116-60.

27. Savarino A, et al. Effects of chloroquine on viral infections: an old drug against today's diseases. Lancet Infect Dis. 2003;3(11):722-7.

28. Thenmozhi P. Molecular detection of dengue virus serotypes from clinical samples prevalent in and around Coimbatore. Coimbatore: PSG Institute of Medical Sciences and Research; 2018.

29. Vabret A, et al. Human (non-severe acute respiratory syndrome) coronavirus infections in hospitalised children in France. J Paed Child Health. 2008;44(4):176-81.

30. Wang N, et al. Structure of MERS-CoV spike receptor-binding domain complexed with human receptor DPP4. Cell Res. 2013;23(8):986.

31. Yu I-M, et al. Crystal structure of the severe acute respiratory syndrome (SARS) coronavirus nucleocapsid protein dimerization domain reveals evolutionary linkage between corona-and arteriviridae. J Biol Chem. 2006;281(25):17134-9.

32. Zhao Z, et al. Description and clinical treatment of an early outbreak of severe acute respiratory syndrome (SARS) in Guangzhou, PR China. J Med Microbiol. 2003;52(8):715-20.

33. Zhou F, Yu T, Du R, Fan G, Liu Y, Liu Z, Xiang J, Wang Y, Song B, Gu X, Guan L. Clinical course and risk factors for mortality of adult inpatients with COVID-19 in Wuhan, China: a retrospective cohort study. The Lancet. 2020;395(10229):1054-62.

34. Zumla A, et al. Rapid point of care diagnostic tests for viral and bacterial respiratory tract infections-needs, advances, and future prospects. Lancet Infect Dis. 2014;14(11):1123-35.

Publisher's Note Springer Nature remains neutral with regard to jurisdictional claims in published maps and institutional affiliations. 